\title{
ANALISIS KOMPOSISI DAN KEANEKARAGAMAN SPESIES TUMBUHAN DI HUTAN DESA BALI AGA TIGAWASA, BULELENG - BALI
}

\author{
Nyoman Wijana \\ Jurusan Biologi, Fakultas IImu Matematika dan IImu Pengetahuan Alam \\ Universitas Pendidikan Ganesha \\ e-mail:wijana_1960@yahoo.com
}

\begin{abstract}
Abstrak
Tujuan penelitian ini adalah untuk mengetahui komposisi dan besarnya indeks keanekaragaman spesies tumbuhan pada vegetasi hutan adat yang ada di Desa Bali Aga Tigawasa-Buleleng.Jenis penelitian ini adalah jenis penelitian eksploratif. Populasi dalam penelitian ini adalah seluruh spesies tumbuhan yang ada di dalam vegetasi hutan adat yang ada di Desa Bali Aga Tigawasa-Buleleng. Metode yang digunakan dalam pengambilan data di lapangan adalah dengan menggunakan metode kuadrat.Teknis pengambilan sampelnya adalah dengan sistematik sampling. Untuk data komposisi spesies dianalisis secara deskriptif. Untuk data keanekaragaman spesies dianalisis dengan menggunakan statistik ekologi. Hasil penelitian ini menunjukkan (1) Terdapat 24 spesies tumbuhan. Spesies yang memiliki nilai desitas relatif paling besar adalahKopi (Anacolosa frutescens) (22,34\%) dan Majegau (Dysoxylum densiflorum). Karakteristik hutan Desa Bali Aga Tigawasa bagian strata bawahnya adalah spesies Anacolosa frutescens dan strata atas adalah Dysoxylum densiflorum; (2) Rata-rata indeks keanekaragaman spesies pada hutan Desa Bali Aga Tigawasa sebesar 3.3829, yang termasuk dalam kategori sedang.
\end{abstract}

Kata kunci :Komposisi Spesies, Keanekaragaman Spesies, Bali Aga

\begin{abstract}
The purpose of this research was to know the species composition and diversity index indigenous plants on forest vegetation in the village of Bali Aga Tigawasa-Buleleng. This research is a kind of exploratory research. The population in this study are all species of plants in the indigenous forest vegetation in the village of Bali Aga Tigawasa-Buleleng. The method used in collecting data in the field is quadrate method. Technical sampling used systematic sampling. For plant species composition data were analyzed by descriptively. For the species diversity of data were analyzed using statistical ecology. The results of this research indicate (1) There are 24 species of plants. Species that have the greatest value relative density is Coffee (Anacolosa frutescens) (22.34\%) and Majegau (Dysoxylum densiflorum). Characteristics Bali Aga village forest Tigawasa bottom layer is Anacolosa frutescens and the top layer is Dysoxylum densiflorum; (2) Average index of species diversity in the forest village of Bali Aga Tigawasa of 3.3829 , which is included in the medium category.
\end{abstract}

Keywords : Species Composition, Species Diversity, Bali Aga 


\section{PENDAHULUAN}

Keunikan Bali bisa dilihat dari kekerabatan di antara mereka. Mereka sangat ingat pada asal muasal dari mana asal mereka. Hal ini melahirkan soroh atau wangsa atau golongan masyarakat. Tatanan masyarakat berdasarkan soroh ini begitu kuat menyelimuti aktivitas kehidupan masyarakat Bali. Beberapa soroh yang selama ini dikenal adalah Warga Pande, Sangging, Bhujangga Wesnawa, Pasek, Dalem Tarukan, Tegeh Pulasari, Arya, Brahmana Wangsa, Bali Aga dan lain-lainnya. Perbedaan pengaruh dari kebudayaan Jawa Hindu di berbagai daerah di Bali dalam zaman Majapahit, menyebabkan adanya masyarakat Bali yaitu Masyarakat Bali-Aga dan masyarakat Bali Majapahit. Khusus soroh Bali Aga, dianggap sebagai Bali Asli. Masyarakat Bali Aga kurang sekali mendapat pengaruh dari kebudayaan Jawa-Hindu dari Majapahit dan mempunyai struktur Orang Bali Aga. Masyarakat Bali Aga pada umumnya mendiami desa-desa di daerah pegunungan seperti Desa Sembiran, Cempaga, Sidatapa, Pedawa dan Tiga Wasa di Kabupaten Buleleng. Desa Tenganan Pegringsingan di Kabupaten Karangasem. Orang Bali Majapahit pada umumnya merupakan bagian yang paling besar dari penduduk Bali (Anonimus, dalam Wijana, 2013a).

$$
\text { Sebagaimana layaknya }
$$

masyarakat asli yang tinggal di daerah pegunungan/perbukitan maka jelas bahwa wilayahnya itu terdiri atas hutan sebagai wilayah yang menjadi sumber kelangsungan hidupnya. Wilayah hutan yang menjadi sumber kelangsungan hidupnya ini dijaga secara ketat dan digunakan secara arif sehingga kelestarian hutan itu tetap terjaga. Di samping itu mereka mengakui dan percaya bahwa hutan itu adalah hutan duwe yaitu hutan milik dan/atau pemberian Tuhan Yang Maha Esa (Ida Sang Hyang Widhi Wasa) sehingga harus dijaga dan dilestarikan. Dengan demikian hutan itu sampai saat ini masih tetap lestari.

Profil masing-masing desa Bali Aga yang ada di Buleleng, meliputi Desa Sidatapa, Desa Cempaga, Desa Pedawa, dan Desa Tiga Wasa memiliki profil desa sebagai berikut. (1) Desa Bali Aga Sidatapa memiliki luas wilayah sebesar 965,4 ha. Dari luas wilayah desa tersebut ha adalah hutan 149,24 ha, perkebunan 882,3 ha dan 29,45 ha pemukiman. (2) Desa Cempaga dengan luas wilayah $9.550,15$ ha yang terdiri dari hutan/tegal 2550 ha, perkebunan 92,65 ha, pertanian 46,42 ha dan pemukiman 6840 ha. (3) Desa Pedawa dengan luas wilayah 16.680 ha yang terdiri dari hutan 8,56 ha, perkebunan 85,106 ha, pertanian 10,15 ha dan pemukiman 18,300 ha. (4) Desa Tiga Wasa dengan luas wilayah 1690 ha yang terdiri dari hutan 8,41 ha, perkebunan 947,17 ha, dan pemukiman 16,75 ha.

Hasil observasi di lapangan dan hasil wawancara dengan beberapa orang masyarakat setempat menyatakan bahwa kondisi hutan di masing-masing desa Bali Aga tersebut masih tetap lestari. Kondisi hutannya sejak dari dahulu hingga saat ini masih tetap seperti biasa. Perubahanperubahan yang terjadi sebagai akibat dari adaptasi terhadap kondisi lingkungan edafik dan klimatik yang mengglobal seperti saat ini. Jenis hutan 
yang ada tersebut termasuk jenis hutan tropika dataran tinggi.

Kondisi di atas tampak sangat kontradiktif dengan kondisi hutan secara umum di Indonesia. Berdasarkan data yang ada untuk tahun 2000, luas kerusakan hutan di Indonesia mencapai 54,65 juta ha yang terdiri dari 9,75 juta ha hutan lindung, 3,9 juta ha hutan konservasi, dan 41 juta ha hutan produksi. Kerusakan lahan di luar kawasan hutan mencapai 41, 69 juta ha (Direktorat Jendral Planologi Kehutanan, Kementerian Kehutanan, 2010). Kerusakan hutan ini akan berdampak pada klimatologi, hidroorologis, tanah, kesehatan, budaya dan lain-lain baik secara lokal, nasional maupun global.

Data dari Dinas Kehutanan Propinsi Bali tahun 2002 menunjukkan bahwa dari luas lahan 127.271,5 ha kawasan hutan yang ada, kondisi tegakan/vegetasi hutannya yang masih bagus seluas 56,06\%, hutan bervegetasi belukar atau semak sebesar $25,55 \%$ dan sisanya berupa hutan kritis atau sangat rawan sampai kosong adalah sebesar $18,39 \%$. Ada 3 faktor penyebab kerusakan hutan di Bali yakni kebakaran, penebangan liar, dan pembibrikan. Kebakaran hutan tahun 2002 mencapai 544,19 ha; penebangan liar 83,17 $\mathrm{m3} / \mathrm{th}$; dan pembibrikan mencapai 5.245, 77 ha (Adnyana dan Suwarna, 2007).

Hutan-hutan yang dikelola oleh pemerintah banyak mengalami gangguan dan perambahan/ilegal logging yang terus berjalan hingga saat ini (Bali Post, 7 Maret 2011), dan bahkan ada kejadian yang cukup menarik yakni masyarakat yang peduli akan kelestarian hutan ditembak dengan senjata pada saat orang tersebut melakukan penghijauan di tengah hutan pemerintah (Bali Post, 12 April 2011). Fenomena lain yang hangat menjadi warta media cetak di Bali adalah meluapnya air Danau Buyan dan Danau Tamblingan sampai merendam pemukiman penduduk, tempat wisata, dan lahan pertanian masyarakat sekitar. Hal ini diprediksi akibat terjadinya alih fungsi lahan yakni dari ekosistem hutan menjadi ekosistem pemukiman dan pertanian (Bali Post, 11 dan 13 April 2011). Hutan yang ada di Desa Bali AgaTigawasa dipandang sebagai suatu tempat suci, di mana pelaksanaan upacara agama khususnya pada piodalan tertentu dilakukan di hutan tersebut. Karena hutan dianggap "suci" oleh masyarakat setempat, maka kondisi hutan di desa tersebut sangat lestari. Berbeda halnya dengan kondisi hutan yang dikelola oleh pemerintah pada umumnya yang telah banyak mengalami degradasi. Sebagaimana diketahui bahwa kondisi hutan yang lestari, memberikan ketertarikan tersendiri bagi ekologiwan untuk mengetahui lebih jauh tentang fenomena dan eksistetensi dari hutan tersebut baik dari sisi biodiversity dan bioconservation. Kondisi yang berkaitan dengan informasi parameter ekologi vegetasi khususnya komposisi dan keanekaragaman spesies tumbuhan yang ada di hutan Desa Bali AgaTigawasa tersebut, belum ada sama sekali bahkan data ilmiah yang dilakukan oleh para peneliti lain pun belum tersedia sama sekali. Kondisi ini menjadikan ketertarikan penulis untuk melakukan penelitian dalam mengkaji biodiversity yang meliputi komposisi 
dan keanekaragaman spesies.Tujuan penelitian ini adalah untuk mengetahui komposisi dan besarnya indeks keanekaragaman spesies tumbuhan pada vegetasi hutan adat yang ada di Desa Bali Aga Tigawasa-Buleleng.

\section{METODE}

Penelitian ini termasuk ke dalam penelitian eksploratif dan deskriptif.Populasi dalam penelitian ini adalah semua spesies tumbuhan yang hidup di seluruh area hutan Desa Adat Bali AgaTigawasa Buleleng. Sampel dalam penelitian ini adalah seluruh spesies tumbuhan yang terkaver oleh kuadrat ukuran $10 \times 10 \mathrm{~m}$ untuk pohon, $5 \times 5 \mathrm{~m}$ untuk sapling, dan $1 \times 1 \mathrm{~m}$ untuk seedling sepanjang transek yang diletakkan pada daerah kajian sebanyak 20 kuadrat. Data dianalisis secara statistik ekologi dan deskriptif.

\section{HASIL DAN PEMBAHASAN \\ Hasil \\ Komposisi Spesies}

Komposisi spesies tumbuhan yang ada di hutan Desa Bali AgaTigawasa disajikan pada Tabel 1.

Tabel 1. Densitas Relatif Spesies Tumbuhan yang Ada di Hutan Desa Tigawasa (Dusun Congkang)

\begin{tabular}{|c|c|c|c|c|c|c|}
\hline No & $\begin{array}{c}\text { Kode } \\
\text { Spesies }\end{array}$ & $\begin{array}{c}\text { Nama } \\
\text { lokal }\end{array}$ & Nama IImiah & $\begin{array}{l}\text { Jumlah } \\
\text { Individu }\end{array}$ & Densitas & $\begin{array}{c}\text { Densitas } \\
\text { Relatif } \\
\end{array}$ \\
\hline 1 & $A$ & Pule & $\begin{array}{l}\text { Alstonia } \\
\text { macrophylla }\end{array}$ & 6 & 0.003 & 3.1915 \\
\hline 2 & B & Majegau & $\begin{array}{l}\text { Dysoxylum } \\
\text { densiflorum }\end{array}$ & 17 & 0.0085 & 9.0426 \\
\hline 3 & $\mathrm{C}$ & Temen & $\begin{array}{l}\text { Graptophyllum } \\
\text { pictum }\end{array}$ & 7 & 0.0035 & 3.7234 \\
\hline 4 & D & Kopi & $\begin{array}{l}\text { Anacolosa } \\
\text { frutescens }\end{array}$ & 42 & 0.021 & 22.3404 \\
\hline 5 & $E$ & Iseh & Agathis alba & 16 & 0.008 & 8.5106 \\
\hline 6 & $\mathrm{~F}$ & Jelulut & Dyera castulata & 10 & 0.005 & 5.3191 \\
\hline 7 & G & Nangka & $\begin{array}{l}\text { Artocarpus } \\
\text { heterophyllus }\end{array}$ & 8 & 0.004 & 4.2553 \\
\hline 8 & $\mathrm{H}$ & Meding & Litsea Sp & 1 & 0.0005 & 0.5319 \\
\hline 9 & I & Lateng & Laportea $s p$ & 2 & 0.001 & 1.0638 \\
\hline 10 & $\mathrm{~J}$ & Sampi & Lasia spinosa & 2 & 0.001 & 1.0638 \\
\hline 11 & K & Sembung & $\begin{array}{l}\text { Blumea } \\
\text { balsamifera }\end{array}$ & 1 & 0.0005 & 0.5319 \\
\hline 12 & L & Udu & Litsea velutina & 1 & 0.0005 & 0.5319 \\
\hline 13 & $M$ & $\begin{array}{l}\text { Kepundun } \\
\mathrm{g}\end{array}$ & $\begin{array}{l}\text { Baccaurea } \\
\text { racemosa }\end{array}$ & 1 & 0.0005 & 0.5319 \\
\hline 14 & $N$ & lyeh-iyeh & Imperata spec. & 2 & 0.001 & 1.0638 \\
\hline 15 & O & $\begin{array}{l}\text { Gintunga } \\
\mathrm{n}\end{array}$ & Bischofia javanica & 5 & 0.0025 & 2.6596 \\
\hline
\end{tabular}




\begin{tabular}{|c|c|c|c|c|c|c|}
\hline 16 & $P$ & Jaka & Arenga pinata & 11 & 0.0055 & 5.8511 \\
\hline 17 & Q & Maja & Aegle marmelos & 3 & 0.0015 & 1.5957 \\
\hline 18 & $\mathrm{R}$ & Gadung & Dioscorea hispida & 21 & 0.0105 & 11.1702 \\
\hline 19 & $S$ & $\begin{array}{l}\text { Belah } \\
\text { Buah }\end{array}$ & Xylocarpus spec. & 12 & 0.006 & 6.3830 \\
\hline 20 & $\mathrm{~T}$ & Klampuak & $\begin{array}{l}\text { Eugenia } \\
\text { accuminatisima }\end{array}$ & 5 & 0.0025 & 2.6596 \\
\hline 21 & $U$ & Kesumba & $\begin{array}{l}\text { Schleichera } \\
\text { oleosa }\end{array}$ & 1 & 0.0005 & 0.5319 \\
\hline 22 & V & Kererek & Cucumis sativus & 5 & 0.0025 & 2.6596 \\
\hline 23 & W & Binong & $\begin{array}{l}\text { Tetrameles } \\
\text { nudiflora }\end{array}$ & 5 & 0.0025 & 2.6596 \\
\hline 24 & $\mathrm{X}$ & Cempaka & Michelia alba & 4 & 0.002 & 2.1277 \\
\hline \multicolumn{4}{|c|}{ Total } & 188 & 0,094 & 100 \\
\hline
\end{tabular}
pada Gambar 1

Dari tabel di atas, selanjutnya dapat dilustrasikan dalam bentuk grafik seperti tampak

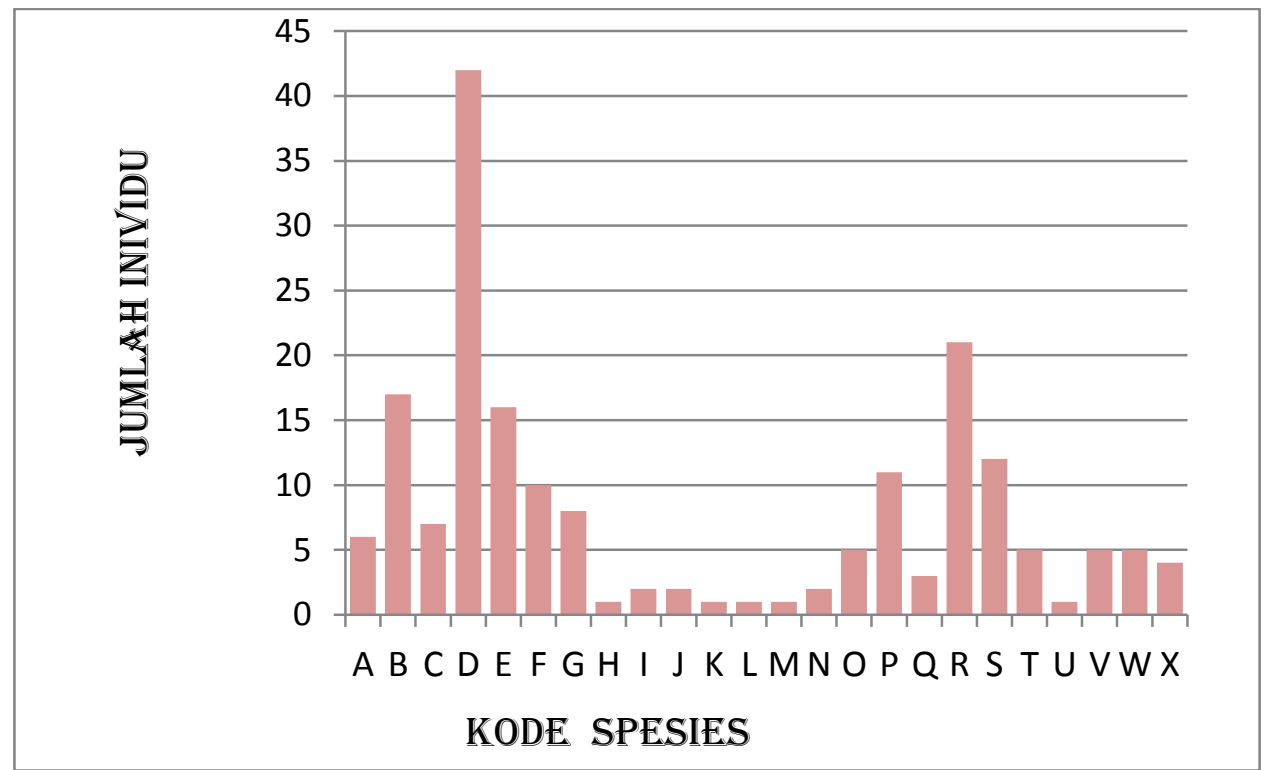

Gambar 1. Densitas Relatif Spesies Tumbuhan yang ada di Hutan Desa Tigawasa (Dusun Congkang) BanjKabupaten Buleleng. Keterangan: Kode spesies lihat Tabel 1

Dari 24 spesies tumbuhan yang ada, spesies yang memiliki nilai densitas relatif paling besar adalah Kopi (Anacolosa frutescens)(22,34\%). Berdasarkan densitas relatif yang ada, tampak bahwa tanaman kopi yang lebih banyak terlihat.Namun berdasarkan pengamatan di lapangan, menunjukkan bahwa spesies kopi ini hanya menempati pada strata bawah, 
sehingga penampakan dari luar, spesies tanaman ini tidak tampak seperti karakter kebun kopi.Tanaman kopi yang ada di hutan tersebut adalah bersumber dari pemencaran yang dilakukan oleh hewan (zookori), yang berasal dari kebun kopi yang dimiliki oleh masyarakat sekitarnya, bukan oleh aktivitas manusia.Tanaman kopi yang ada tersebut masih kecil, belum menunjukkan habitus seperti tanaman kopi yang ada di kebun.Untuk itu, karakteristik dari tumbuhan tersebut lebih relevan diindikasikan oleh spesies Majegau (Dysoxylum densiflorum). Hal ini dilandasi oleh hasil observasi di lapangan, yang menunjukkan bahwa spesies tumbuhan Majegau memiliki perkiraan tinggi lebih dari 30 meter, batang pohon besar, densitas relatifnya juga ada diurutan ketiga (9\%).
Dari data di atas, hal ini bermakna bahwa bila hutan ini dilihat dari luar, maka spesies Majegau,kayu batu, iseh, kayu jelema, sebagai karaktersitik hutan strata atas, sedangkan untuk kondisi di dalamnya, sebagai strata bawah, spesies tumbuhan kopi sebagai karakteristiknya. Sedangkan untuk spesies tumbuhan gadung, tidak dijadikan sebagai indikator karakter karena spesies tumbuhan tersebut hanyalah sebagai tumbuhan liana.

\section{Keanekaragaman Spesies}

Rekapitulasi keanekaragaman spesies (dalam Bentuk Variasi Umum (H").Hutan Desa Desa Bali AgaTigawasa disajikan pada Tabel 1.2.

Tabel 2. Rekapitulasi Indeks Diversitas dalam Bentuk Variasi Umum (H") pada Hutan Desa Bali AgaTigawasa

\begin{tabular}{|c|c|c|c|}
\hline Plot & H' & Plot & H' \\
\hline 1 & 3.8448 & 11 & 3.5482 \\
2 & 4.7741 & 12 & 3.6963 \\
3 & 3.5349 & 13 & 3.1354 \\
4 & 3.0535 & 14 & 2.4564 \\
5 & 2.3663 & 15 & 3.0998 \\
6 & 3.0827 & 16 & 3.4383 \\
7 & 3.0666 & 17 & 2.9508 \\
8 & 4.0357 & 18 & 3.6791 \\
9 & 3.4607 & 19 & 2.5609 \\
10 & 3.9192 & 20 & 3.9550 \\
\hline Jumlah & & & 67.6588 \\
\hline Rata-rata & & & 3.3829 \\
\hline
\end{tabular}

bahwa rata-rata indeks keanekaragaman spesies adalah sebesar 3,3829. Indeks ini menurut acuan yang disampaikan oleh Barbour et al (1987) termasuk ke dalam kategori
sedang.Berdasarkan analisis per kuadrat, tampak bahwa kuadrat 2 memiliki indeks yang tertinggi (4.7741) dan kuadrat 5 sebagai kuadrat dengan indeks terendah (2.3663). Rentangan indeks diversitas berdasarkan 
kategorinya berada pada rentangan rendah-tinggi.

\section{Nilai Kemerataan (E) dan Nilai Kekayaan (R) Spesies Tumbuhan}

Rekapitulasi Nilai Kemerataan Spesies (E) dan Nilai Kekayaan Spesies (R) Tumbuhan pada Masingmasing Hutan disajikan pada Tabel 1.3

Tabel 3. Rekapitulasi Nilai Kemerataan (E) dan Nilai Kekayaan (R) Spesies Tumbuhan pada Masing-masing Hutan

\begin{tabular}{|c|c|c|c|c|c|}
\hline Nama Desa & $\begin{array}{c}\text { Jumlah } \\
\text { Jenis }\end{array}$ & $\begin{array}{c}\text { Total } \\
\text { Individu }\end{array}$ & $\mathrm{H}^{\prime \prime}$ & $\begin{array}{c}\mathrm{R} \\
\text { (Kekayaan) }\end{array}$ & $\mathrm{E}$ (Kemeraataan) \\
\hline Desa Tigawasa & 24 & 188 & 3.1981 & 4.3923 & 1.0063 \\
\hline
\end{tabular}

Terkait dengan kekayaan dan kemerataan spesies, berdasarkan hasil rekapitulasi data diperoleh nilai dari kemerataan spesies (E) sebesar 1.0063 lebih kecil dari kekayaan spesies $(R)$ yaitu 4,3923. Hal ini berarti bahwa yang lebih berperan dalam menentukan indeks keanekaragaman spesies adalah kekayaan spesies. Sebagaimana diketahui bahwa keanekaragaman spesies terdiri atas dua komponen yang menyusunnya yaitu kemerataan spesies dalam komunitas dan kekayaan spesiesnya. Di antara kedua komponen tersebut, masing-masing memiliki indeks tertentu. Apabila nilai indeksnya sama atau mendekati sama maka antara kemerataan spesies dan kekayaan spesies yang menentukan indeks keanekaragaman memiliki kontribusi yang sama atau seimbang. Apabila hal itu terjadi sebaliknya, maka salah satu komponen memberikan kontribusi yang lebih besar. Hal ini bermakna bahwa keanekaragaman spesies tumbuhan yang ada di dalam suatu komunitas ditentukan oleh kekayaan spesies dan kemerataan spesies yang ada di dalam komunitas tersebut. Dalam suatu komunitas komponen kekayaan spesies dapat lebih mendominasi atau sebaliknya yaitu kemerataan spesies yang lebih mendominasi, dan atau keduanya memiliki daya kontribusi yang seimbang.

\begin{tabular}{|c|c|}
\hline $\begin{array}{l}\text { Faktor yang } \\
\text { Keanekaragaman } \\
\text { Tumbuhan }\end{array}$ & $\begin{array}{r}\text { Mempengaruhi } \\
\text { Spesies }\end{array}$ \\
\hline $\begin{array}{l}\text { Rekapitulasi } \\
\text { nempengaruhi }\end{array}$ & $\begin{array}{c}\text { faktor yang } \\
\text { keanekaragaman }\end{array}$ \\
\hline $\begin{array}{l}\text { h, kelengasan } \\
\text {, intensitas } \\
\text { n di Desa Tigaw }\end{array}$ & $\begin{array}{l}\text { ayah, pH tana } \\
\text { aya disajikan pac }\end{array}$ \\
\hline
\end{tabular}

Tabel 4. Rekapitulasi Faktor yang Mempengaruhi Keanekaragaman Spesies Tumbuhan Yaitu Bahan Organik Tanah, Kelengasan Tanah, pH Tanah, Suhu, Intensitas Cahaya pada Area Hutan di Desa Tigawasa

\begin{tabular}{|c|c|c|c|c|c|}
\hline Plot & BOT (\%) & pH & KT(\%) & Suhu ( $\left.{ }^{\circ} \mathbf{C}\right)$ & $\begin{array}{l}\text { Intensitas Cahaya } \\
\text { (lux) }\end{array}$ \\
\hline 1 & 5.208 & 6.3 & 39.81 & 27.61 & 330 \\
\hline
\end{tabular}




\begin{tabular}{|c|c|c|c|c|c|}
\hline 2 & 2.91 & 6.4 & 42.21 & 28.4 & 285 \\
3 & 6.268 & 6.3 & 43.406 & 30 & 190 \\
4 & 2.18 & 5.5 & 32.095 & 29.9 & 302 \\
5 & 5.414 & 6.1 & 39.95 & 30.1 & 289 \\
6 & 3.794 & 6.9 & 40.069 & 30.5 & 240 \\
7 & 10.44 & 6 & 43.96 & 30.6 & 346 \\
8 & 4.22 & 6 & 41.777 & 30.6 & 208 \\
9 & 6.282 & 6 & 49.213 & 30.4 & 206 \\
10 & 5.992 & 5.7 & 45.954 & 30.1 & 600 \\
11 & 9.666 & 6 & 45.577 & 30.4 & 509 \\
12 & 13.038 & 5.4 & 45.928 & 30.3 & 339 \\
13 & 6.094 & 6 & 48.373 & 31.3 & 411 \\
14 & 8.088 & 6 & 45.427 & 31 & 510 \\
15 & 6.206 & 6.2 & 43.117 & 31 & 526 \\
16 & 4.294 & 6.3 & 40.962 & 30.6 & 394 \\
17 & 5.588 & 6.5 & 41.272 & 30.6 & 732 \\
18 & 4.468 & 6 & 41.39 & 31 & 516 \\
19 & 3.618 & 6.3 & 41.304 & 29.9 & 489 \\
20 & 3.72 & 6.1 & 39.697 & 31.3 & 514 \\
\hline Total & 117.4880 & 122 & 851.4910 & 605.61 & 7936 \\
\hline Rata-rata & 5.8744 & 6.1 & 42.5746 & 30.2805 & 396.8 \\
\hline
\end{tabular}

Pada tabel di atas terlihat nilai rata-rata bahan organik tanah yaitu sebesar 5,8744\%, $\mathrm{pH}$ tanah 6,1, Kelengasan Tanah 42,57\%, suhu $30,28^{\circ} \mathrm{C}$, dan intensitas cahaya 396.8 lux.
Hasil Analisis Korelasi antara indeks keanekaragaman spesies tumbuhan dengan bahan organik tanah, $\mathrm{pH}$ tanah, dan kelengasan tanah pada area hutan di Desa Tigawasa disajikan pada Tabel 5.

Tabel 5. Hasil Analisis Korelasi Antara Indeks Keanekaragaman Spesies Tumbuhan dengan Bahan Organik Tanah, pH Tanah, Kelengasan Tanah, Suhu, dan Intensitas Cahaya pada Area Hutan di Desa Tigawasa

\begin{tabular}{|l|r|r|r|r|}
\hline Model & $\mathrm{R}$ & $\mathrm{R}$ Square & Adjusted R Square & $\begin{array}{c}\text { Std. Error of the } \\
\text { Estimate }\end{array}$ \\
\hline 1 & $.509^{\mathrm{a}}$ & .259 & .005 & .5922534 \\
\hline
\end{tabular}

a. Predictors: (Constant), I.CAHAYA, pH, KT, SUHU, BOT

\begin{tabular}{|l|c|c|c|c|c|}
\hline Model & $\begin{array}{c}\text { Sum of } \\
\text { Squares }\end{array}$ & df & Mean Square & F & Sig. \\
\hline
\end{tabular}




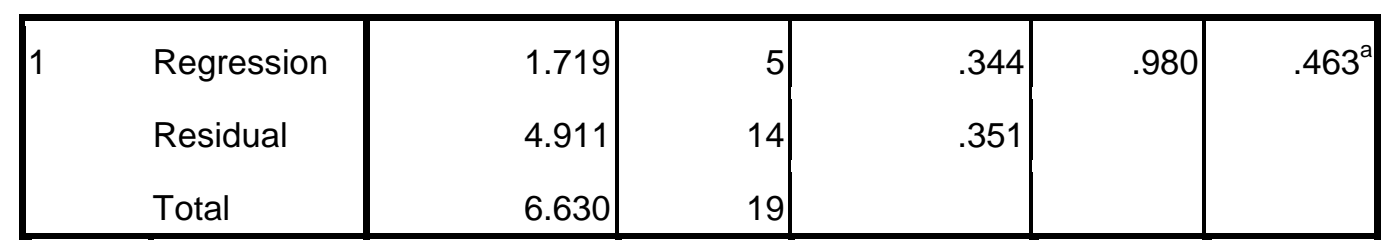

a. Predictors: (Constant), I.CAHAYA, pH, KT, SUHU, BOT

b. Dependent Variable: I.KEANEKARAGAMAN

Berdasarkan hasil uji regresi ganda diperoleh besaran $\mathrm{R}^{2}$ (Adjusted $R$ Square) adalah 0,05 . Hal ini mengindikasikan bahwa $5 \%$ indeks keanekaragaman dapat dijelaskan oleh faktor lingkungan sedangkan 95\% disebabkan faktor lain yang tidak diperhitungkan.

\section{PEMBAHASAN Komposisi Spesies}

Sebagaimana tertera pada Tabel 1.1 bahwa jumlah spesies yang menyusun vegetasi hutan Desa Bali Aga Tigawasa adalah sebanyak 24 spesies tumbuhan. Dari 24 spesies tumbuhan tersebut ada spesies tertentu yang memiliki densitas relatif yang tinggi dan yang lainnya memiliki densitas relatif yang rendah.

Kondisi ini menunjukkan bahwa masing-masing spesies memiliki rentangan habitat tertentu. Pada setiap kisaran lingkungan tertentu memiliki parameter lingkungan tertentu pula, baik faktor edafik maupun faktor klimatiknya. Setiap terjadi perubahan kisaran lingkungan, maka terjadi pula perubahan faktor edafik dan klimatiknya. Masing-masing spesies memiliki kisaran lingkungan yang sesuai dengan kebutuhan hidupnya (Polunin, 1990). Oleh karenanya, besarnya jumlah spesies tumbuhan yang ada di masing-masing habitat tertentu sangat berkorelasi dengan kondisi lingkungannya.

Hasil penelitian yang dilakukan oleh Wijana (1994) terdapat 34 spesies tumbuhan yang ada di hutan sawo kecik Taman Nasional Bali Barat; Wijana (2005) melakukan penelitian di hutan Tenganan Pegringsingan, Karangasem menyimpulkan ada sebanyak 67 spesies tumbuhan yang menyusun vegetasi yang ada di hutan bukit kangin dan bukit kauh Desa Tenganan. Penelitian yang sama untuk tahun 2009, diperoleh bahwa terdapat 43 spesies dimana digunakan untuk bahan sandang, untuk bahan pangan, untuk bahan pangan, untuk obatobatan, untuk keperluan upacara agama, dan untuk keperluan rumah tangga. Lebih lanjut Wijana (2010) melakukan penelitian di kawasan hutan penyangga danau Buyan, menyimpulkan bahwa ada sebanyak 26 spesies tumbuhan di hutan sebelah barat danau, 23 spesies tumbuhan di hutan sebelah timur dan ada sebanyak 40 spesies tumbuhan secara keseluruhan spesies tumbuhan yang ada di hutan penyangga Danau Buyan.

Dari data hasil-hasil penelitian yang dilakukan oleh Wijana (2013b), tampak bahwa masing-masing lokasi memiliki komposisi spesies tumbuhan yang berbeda-beda. Hal ini sangat tergantung dari altitude, latitude, faktor 
edafik, dan faktor klimatik dari daerah kajian masing-masing.

\section{Keanekaragaman Spesies}

bahwa $\begin{array}{r}\text { Dari Tabel } 2 \text { di atas tampak } \\ \text { rata-rata }\end{array}$ keanekaragaman spesies adalah sebesar 3,3829. Indeks ini menurut acuan yang disampaikan oleh Barbour et al (1987) termasuk ke dalam kategori sedang. Dari hasil analisis terhadap ekuitabilitas dan kekayaan spesies yang merupakan komponen dari konsep keanekaragaman spesies, nampak bahwa indeks kekayaan spesiesnya lebih besar dari indeks kemerataan atau ekuitabilitasnya. Hal ini berarti bahwa kondisi di area penelitian sesuai dengan pernyataan yang disampaikan oleh Polunin (1990), menyebutkan bahwa kisaran lingkungan tertentu memiliki kisaran parameter edafik tertentu pula. Artinya bahwa unsur-unsur hara tanah yang ada di lokasi kajian tidak terdistribusi secara merata, sehingga kemerataan spesies yang hidup di atasnya juga tidak merata. Hasil observasi dan analisis, tampak bahwa komponen kekayaan spesies atau macam spesies yang hidup di lokasi kajian cukup tinggi.

Dalam penelitian ini, faktorfaktor yang berpengaruh terhadap keanekaragaman spesies tumbuhan didata dan diuji di laboratorium yaitu bahan organik tanah, kelengasan tanah, $\mathrm{pH}$ tanah, suhu, dan intensitas cahaya seperti tampak pada Tabel 1.4 di atas. Selanjutnya dari data di atas dilakukan analisis statistik korelasi regresi untuk melihat hubungan faktorfaktor yang berpengaruh terhadap keanekaragaman spesies ( $\left.\mathrm{H}^{\prime}\right)$.
Nilai uji korelasi menunjukkan hubungan yang lemah (tidak signifikan) antara indeks keanekaragaman spesies dengan faktor-faktor prediktor. Dari hasil analisis statistik tersebut bukan berarti faktor prediktor tersebut tidak memiliki peranan penting dalam ekosistem.Faktor-faktor itu menjadi salah satu penentu kelangsungan hidup organisme yang hidup di dalam maupun di atas tanah.Faktor edafik dan faktor klimatik merupakan faktor yang terkait dengan fisiologis dari suatu vegetasi.Faktor-faktor tersebut dipentingkan dalam kelangsungan hidup vegetasi.Walau secara statistik menunjukkan korelasi yang rendah tetapi hukum-hukum Shelford dan hukum faktor pemicu tetap berlaku di alam ini.

Nilai rata-rata faktor edafik yang ada di hutan Desa Tigawasa yaitu bahan organik tanah sebesar 5,8744\%, bahan organik tanah yang bagus untuk pertumbuhan tanaman adalah untuk pertumbuhan suatu tanaman sebesar 15\% (Sarna, 1993), jadi kandungan BOT yang ada di hutan Desa Tigawasa masih dapat dikatakan mendukung pertumbuhan vegetasi. Rata-rata $\mathrm{pH}$ tanah 6,1, Dalam Barbour et al (1987), dijelaskan bahwa $\mathrm{pH}$ yang mendekati netral (antara 6,5 - 7,5) paling baik bagi ketersediaan unsur hara dan baik bagi pertumbuhan tumbuhan, jadi $\mathrm{pH}$ tanah hutan yang ada di Desa Tigawasa termasuk dalam kategori mendekati baik untuk pertumbuhan.

Nilai kelengasan tanah sebesar $42,57 \%$, kelengasan tanah yang baik untuk pertumbuhan suatu tanaman sebesar 25\% (Hardjowigeno, 1987). jadi kandungan kelengasan tanah dapat dikatakan mendukung 
pertumbuhan vegetasi. Nilai rata-rata suhu udara sebesar $30,28^{\circ} \mathrm{C}$, menurut Barbour, et al (1987), suhu optimum untuk produktivitas tumbuhan adalah $15^{\circ} \mathrm{C}$ dan $25^{\circ} \mathrm{C}$ terutama untuk fotosintesis tumbuhan, jadi suhu udara di hutan Desa Tigawasa masih masuk dalam kategori baik untuk pertumbuhan. Nilai rata-rata intensitas cahaya sebesar 396,8 lux, intensitas cahaya dalam suatu ekosistem adalah bervariasi. Faktor intensitas cahaya sangat berpengaruh terhadap fisiologis tumbuhan terutama dalam fisiologis fotosintesis. Dalam pengaruhnya tersebut, intesitas cahaya yang diperlukan oleh tumbuhan untuk aktivitas fotosintesis, mengikuti kurve normal, artinya pada waktu tertentu dengan intensitas cahaya tertentu, laju fotosintesis berlangsung sesuai dengan besarnya intensitas cahaya yang diterima.

\section{SIMPULAN}

Dari hasil penelitian ini dapat disimpulkan :

Terdapat 24 spesies tumbuhan yang menyusun vegetasi hutan yang ada di hutan Desa Bali Aga Tigawasa;

Spesies tumbuhan yang memiliki nilai desitas relatif paling besar adalahKopi (Anacolosa frutescens)(22,34\%) dan Majegau (Dysoxylum densiflorum);

Karakteristik hutan Desa Bali Aga Tigawasa bagian strata bawahnya adalah spesies Anacolosa frutescens dan strata atas adalah Dysoxylum densiflorum;

Rata-rata indeks keanekaragaman spesies pada hutan Desa Bali Aga Tigawasa sebesar 3.3829, yang termasuk dalam kategori sedang.

\section{DAFTAR PUSTAKA}

Adnyana, Sandi I Wayan dan Suwarna, I wayan. 2007. Permasalahan dan Kerusakan Lingkungan Hidup. Dalam Buku Kearifan Lokal Dalam Pengelolaan Lingkungan Hidup. Denpasar : UPT Penerbit Universitas Udayana.

Bali Post. 2011. Air Danau Buyan Capai Tepi Jalan. Selasa Kliwon, 12 April 2011 hal. 12.

Bali Post. 2011. Air Danau Buyan dan Tamblingan Terus Meluap. Senin Wage, 11 April 2011 hal. 12.

Bali Post. 2011. Air Danau Meluap Warga Harus Pindah. Rabu Umanis, 13 April 2011 hal. 11.

Bali Post. 2011. Obok-Obok Hutan Sepang Polhut hanya Temukan Balok Kayu. Senin Wage, 7 Maret 2011 hal. 12.

Barbour, M. G; J. H. Burk and W. D. Pitts. 1987. Terrestrial Plant Ecology. Inc. California : The Benjamin/ cummings Publishing Company.

Direktorat Jendral Planologi Kehutanan, Kementerian Kehutanan. 2010. "Buku Data dan Informasi Pemanfaatan Hutan Tahun 2010".Tersedia pada http://www.dephut.go.id/INFORMAS I/PROPINSI/BALI/bali.html (diakses tanggal 9 Pebruari 2011).

Hardjowigeno, Sarwono. 1987. IImu Tanah. Jakarta : PT. Mediyatama Sarana Perkasa.

Polunin. 1990. Pengantar Geografi Tumbuhan dan Beberapa IImu Serumpun. Yogyakarta: UGM. 
Sarna, Ketut; Nyoman Wijana; I Nengah Sumardika. 1993. Sejarah dan Komposisi Spesies Tumbuhan Desa Adat Penglipuran, Bangli. Laporan hasil Penelitian. Tidak diterbitkan.

Wijana, Nyoman. 2013a. Analisis struktur vegetasi hutan adat, upaya pengelolaan berbasis kearifan lokal dan pemberdayaan masyarakat melalui pendekatan ergologi di desa bali aga Buleleng - Bali. Laporan Hasil Penelitian. Tidak Diterbitkan.

Wijana, Nyoman. 2013b. Pengelolaan Hutan Berbasis Kearifan Lokal di Desa Tigawasa Kecamatan Banjar, Kabupaten Buleleng. Makalah disampaikan dalam seminar nasional yang diselenggarakan oleh FMIPA Undiksha, tanggal 30 November 2013. Dimuat dalam prosiding dengan ISBN 978-6021213-47-6.

Wijana, Nyoman; Ida Bagus Jelantik Swasta; I Nengah Sumardika. 2010. Analisis ABC Environment pada Ekosistem Tumpang Tindih (Overlap Ecosystem) dalam Kaitannya dengan Penurunan Kualitas Air, Eutrofikasi, dan
Rencana Pemantauan Lingkungan (RPL) Danau Buyan Kecamatan Sukasada Kabupaten Buleleng. Laporan Hasil Penelitian. Tidak Diterbitkan.

Wijana, Nyoman dan I Nengah Sumardika. 2009. Pelestarian Jenis-Jenis Tumbuhan Berguna Melalui Kearifan Lokal di Desa Adat Tenganan Pegringsingan, Kabupaten Karangasem, Bali. Dimuat dalam prosiding Konservasi Flora Indonesia dalam Mengatasi Dampak Pemanasan Global. Kebun Raya "Eka Karya - LIPI. Hal. 724 731. ISBN 978-979-799-447-1.

Wijana, Nyoman dan I Nengah Sumardika. 2005. Analsis Vegetasi Hutan Bukit Kangin Desa Adat Tenganan Pengringsingan, Kabupaten Karangasem. Laporan Hasil Penelitian. Tidak Diterbitkan.

Wijana, Nyoman. 1994. Analisis Struktur Tegakan dan Komposisi Vegetasi Hutan Sawo Kecik serta Hubungannya dengan Beberapa Faktor Edafik di Taman Nasional Bali Barat Propinsi Bali. Tesis S-2 Fakultas Pasca Sarjana Universitas Gajah Mada, Yogyakarta. 